\title{
生教材を活用したタスクベースの会話教材の開発 \\ Development of Task-Based Teaching Material for Conversation Using Realia
}

\section{趙 晨 / 鄥 䑣 / 滕 安麗 香港理工大学}

\section{要旨}

本稿では、海外で日本語を学ぶ学習者向けに作成した会話教材について議論する。 従来の定形型の会話練習は文法重視のものが多く、実用性と楽しさに久けていた。そ の問題点を解決すべく、より学習者の興味を引き出せるよう、「買い物」をテーマとし たタスクベースの会話教材を開発することにした。また、中国や香港の学習者は直接 日本文化や社会に触れたり、日本人と話したりする機会が少ないという状況を考慮し、 日本のドラマやテレビ番組といった海外の学習者にとっての有効なリソースを生教材 として活用し、言語と日本文化の両方を取り扱うことにした。

教材の構造としては、コンビニでの買い物という簡単な会話練習から始まり、学習 者を引き付けるためのウォーミングアップを行うこととした。そして、次にデパート での買い物の場面で、より複雑な買い物の会話練習を行う。さらに、タスク先行型の ロールプレイを通して、さらなる学習意欲につなげることを目的とした。最終的な活 動として、コミュニケーション活動を実践的に行うことにより、学習者に達成感を与 えることも出来るのではないかと考えた。

キーワード:

タスクベースの会話、学習意欲、タスク先行型ロールプレイ、実用性 


\section{生教材を活用したタスクベースの会話教材の開発}

趙 晨 / 鄥 肜 / 滕 安麗

香港理工大学

\section{1.はじめに}

これまでの会話教材は文法重視の傾向があり、仮想現実での文法項目の使用を会話 練習での目的としていたため、学習者の興味を引き出せない恐れがあった。また、 Long \& Crookes（1992)が指摘するように、そのように文法ばかりを重視した教室活動を行 っていれば、学習者は現実のコミュニケーション場面で何をどのように話せばいいの かがわからないという問題もあった。

そこで、現実のコミュニケーションに近い状況で学習者に会話を練習してもらおう と考え、筆者らは授業デザインをすることにした。しかし、海外の学習者にとって、 直接日本人と話寸機会は少ないため、日本人との会話を想定したタスクをデザインす ることが果たして有効なのかという疑問も湧いてきた。また、中国や香港の学習者の 現状を鑑みると、日本のテレビ番組やドラマなどが学習者の貴重なリソースになって いることから、筆者らはそういった生教材から教室活動をデザインすることができな いかと考えるに至った。そこで、本稿では、「買い物」をテーマにした会話教材で、ど のように日本のテレビ番組やドラマといった生教材を取り入れることができるのかそ の事例を報告する。

\section{2. 本教材の目的とその対象}

本教材を用い、「本物」の日本語に触れることにより、学習者が言語を知識として学 ぶだけではなく、日本の習慣や考え方、自国の文化との違いや共通点を考えるきっか けにもなるのではないかと考えている。また、実際のコミュニケーションと教科書の 会話とのギャップを学習者に気づかせ、学習者自身が考えながら、より自然な会話が できるように支援することも本教材では意識している。

本教材を使用寸る学習者にはある程度の日本語の知識を必要とする。目安として日 本語能力試験 N3 レベル以上の学習者を対象としている。具体的には以下の 2 種類の学 習者に向いていると考える。

1. 初級の学習を終え、それに相応する会話力を持つ学習者

2. 中級の学習を終え、「話す」能力が不足し、会話力を向上させたいと考えてい る学習者、または、より自然な会話ができるようになりたい学習者 


\section{3. 内容構成}

本教材では、「買い物」をテーマに、易しい場面からより複雑な場面につながる3つ の部分から構成されている。

\section{表 1 教材の構成}

\begin{tabular}{|c|c|c|}
\hline 易 & 1 & $\begin{array}{l}\text { 一番身近なコンビニでの買い物を学習寸る。数字・お金の言い方の復習から日 } \\
\text { 本のコンビニ文化の紹介まで、「コンビニ」をめぐって会話・練習が展開され } \\
\text { ている。ほとんどは決まり文句なので、比較的に簡単な表現から始まる。 }\end{array}$ \\
\hline$\downarrow$ & 2 & $\begin{array}{l}\text { デパートでの買い物を学習する。店員とのコミュニケーションが必要とされる } \\
\text { ため、会話はより複雑になる。様々なロールプレイを通して買い物でよく使わ } \\
\text { れる言語表現を学習する。 }\end{array}$ \\
\hline 難 & 3 & $\begin{array}{l}\text { 值引きの言い方と方法を学習する。学習した内容を学習者自身が利用し、実際 } \\
\text { のコミュニケーション活動に応用する。 }\end{array}$ \\
\hline
\end{tabular}

\section{4. 各部分の構成}

\section{1.コンビニの場面}

コンビニでの買い物は簡単で、話す必要がないと思われがちではあるが、留学経験 のある筆者らの経験では、実際には時々店員の話す内容が聞き取れなくて、対応でき ないことが多々あった。また、日本のコンビニ文化は中国や香港のものと違うところ が多く、コンビニを支障なく利用するのは外国人にとって難かしいことである。そこ で日本のコンビニ文化の紹介を取り入れながら、以下の授業案を作成した。

\section{表 2 コンビニの場面の流れ}

\begin{tabular}{|c|c|}
\hline 活動 & 内容 \\
\hline 1、ディクテーション & $\begin{array}{l}\text { ウォーミングアップとして、実際のコンビニでのお金の } \\
\text { やり取りの会話を聞いて、数字をディクテートする。こ } \\
\text { れまで学習した内容から授業を始めるのは学習者にとつ } \\
\text { ても理解しやすいのではないかと考える。また、必要な } \\
\text { 背景知識として、店員の決まり文句を学習する。 }\end{array}$ \\
\hline 2、会話練習 & 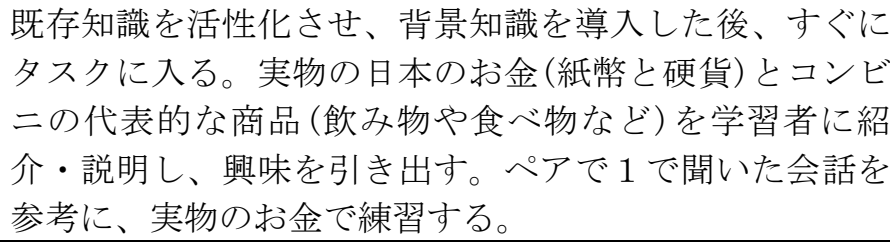 \\
\hline 3、ディスカッション & $\begin{array}{l}\text { 日本のコンビニ文化を導入する前作業として、香港のコ } \\
\text { ンビニの状況や学習者自身のコンビニの使用状況や経験 } \\
\text { などについてペアやグループで話し合う。その。時、教師 } \\
\text { は教室内の学習者たちのコミュニケーションを促進す } \\
\text { る。また、まとめとして教師はコンビニに関する写真や } \\
\text { ニュースなどの情報を提供し、学習者の興味を引き出す。 }\end{array}$ \\
\hline
\end{tabular}




\begin{tabular}{|c|c|}
\hline 4、ビデオ (生教材) の視聴 & $\begin{array}{l}\text { 人気ドラマ'のコンビニのシーンを集めたビデオを見せ } \\
\text { る。登場人物の話すスピードが速いため、穴埋め練習で } \\
\text { キーワードだけを聞き取れるようにする。その後、教師 } \\
\text { はキーワードに関するコンビニ文化の説明をする。また、 } \\
\text { ビデオの中にあるいわゆる間違ったとされる言い方も紹 } \\
\text { 介する。 }\end{array}$ \\
\hline 5、ドリル練習 & $\begin{array}{l}\text { 文型「〜ましょう」の練習問題ではあるが、実際にはコ } \\
\text { ンビニの文化を教えるものにもなっている。学習者が実 } \\
\text { 際の場面で練習問題にあるようなことを聞かれたら、そ } \\
\text { れに反応できるようになることを目指している。 }\end{array}$ \\
\hline 6、会話練習 & $\begin{array}{l}\text { コンビニでの会話を作成する。アウトプット中心で、こ } \\
\text { の単元で学習した内谷を使い、学習者に会話を作っても } \\
\text { らう。 }\end{array}$ \\
\hline
\end{tabular}

本単元は文化導入を重視しているため、実物のお金や商品を展示することと映像を 通してより実体験に近い状況を作るのが一つのポイントである。単に絵を見せて練習 するのは学習者にとって退屈になりがちなので、あらゆる資源や手段を利用し、学習 者の興味を引き出す。また、文化導入とはいえ、学習者中心のアウトプット練習もた くさん導入されている。既存知識を活性化させるためのお金のやり取りの練習から、 意識高揚タスクとして、写真をもとに、学習者に日本のコンビニにはどのようなサー ビスがあるのかを考えてもらい会話を完成させる練習まで、少しずつハードルを上げ ていくように設計してある。

\section{2. デパートの場面}

本単元では、「タスク先行型ロールプレイ」を用いる。タスク先行型ロールプレイは、 実際のコミュニケーション場面で求められる「伝達内容から表現形式へ」といった思 考の流れを用いており（小山, 2008）、学習者により実践的な会話の機会が与えられる と考え、本実践では取り入れることにした。学習者は最初にロールプレイを行い、そ の後人気ドラマやバラエティ番組にある買い物の場面をモデル会話として視聴する。 そして、モデル会話の言語表現を確認した後で、同様の目的のロールプレイを再度行 う。具体的な流れは以下の通りである。

1 フジテレビ『結婚できない男』(2006 年) 第 4 話と第 6 話、TBS テレビ『夜行観覧車』(2013 年)第 1 話 


\section{表 3 デパートの場面の流れ}

\begin{tabular}{|c|c|}
\hline 活動 & 内容 \\
\hline ロールプレイ I & $\begin{array}{l}\text { 1. ロールカードの提示: 役割・状況・課題を確認する。 } \\
\text { 2. ロールプレイの実施 : 学習者はぺアになり、自由にロール } \\
\text { プレイを行う。 } \\
\text { 3. ロールプレイの振り返り : 自分の言いたいことがうまく言え } \\
\text { たかどうか、どんなところが難しかつたか、学習者自身で } \\
\text { 問題点を考える。 }\end{array}$ \\
\hline ビデオ(生教材)の視聴 & 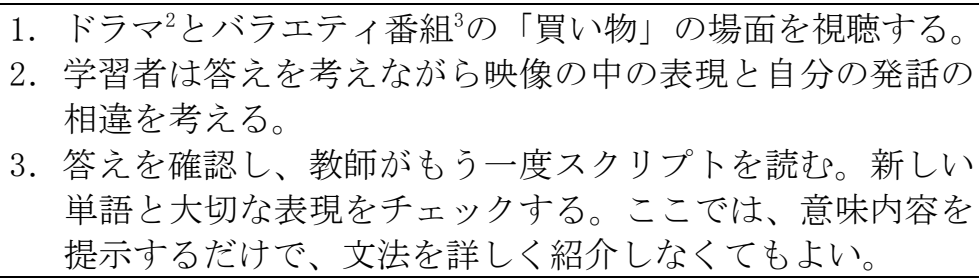 \\
\hline $\begin{array}{l}\text { モデル会話の視聴と } \\
\text { 言語表現の確認 }\end{array}$ & $\begin{array}{l}\text { 1. ロールプレイ I の内容に沿ったモデル会話を聞く。 } \\
\text { 2. 学習者は答えを考え、もう一度買い物の場面での談話構造 } \\
\text { とよく使う表現を確認し、自分の問題点の答えを考える。 } \\
\text { 3. 答えを一緒に確認し、全体の意味の確認を行う。新しい単 } \\
\text { 語も紹介する。 } \\
\text { 4. 学習者は書き起した会話を確認し、それぞれの発話の動き } \\
\text { について考える。 } \\
\text { 5. 例を挙げながら、表現を紹介する。 }\end{array}$ \\
\hline ロールプレイ II & $\begin{array}{l}\text { 1. タスク } 1 \text { をもう一度練習し、学習者に前回の問題点が改善 } \\
\text { されたかどうか、勉強した表現が使えるようになったかど } \\
\text { うかを確認する。 } \\
\text { 2. 教師がフィードバックを行う。誤用がある場合、プロンプ } \\
\text { トやリキャストなど、暗示的な方法を使って訂正する。 } \\
\text { 3. 違った要素を取り入れたタスク } 2 \text { を練習する。学習者に勉 } \\
\text { 強した表現が活用できるようになったか確認する。 }\end{array}$ \\
\hline
\end{tabular}

ここでは、ロールプレイを 2 回行うことがポイントである。1回目では、習った言 語知識を活性化させ、学習者自身に欠けているものを意識させることが重要である(小 山, 2002)。そして、ビデオとモデル会話の聴解、言語表現の確認を通して、自然なコ ミュニケーションの場面で学習者に自分の問題点に沿って、答えを見つけてもらう機 会を与える。2 回目のロールプレイでは、学習したことをその場ですぐに応用し、学 習目標をどれだけ出来るようになったかを確認する（ラミレス・ハラ, 2009）。また、 ロールプレイ 1 と 2 の比較によって、学習者に学習成果を実感させることで、さらな る学習意欲につながることもできるのではないだろうか。

\footnotetext{
2 フジテレビ『結婚しない』(2012 年) 第 3 話
}

${ }^{3}$ TBS テレビ『ひみつの嵐ちゃん！』(2008/9/18，2010/8/26、2011/3/31 放送) 


\section{3. 実践的な活動}

「買い物」の会話授業を通し、学習者ができるようになったことを確かめるために 実践的な活動を行う。海外にいる日本語学習者は実際に日本に行って買い物するチャ ンスがないため、より学習者にコミュニケーションできる場を提供する必要がある。 また、さらにワンステップ上を目指すため、買い物する時の值引きの方法や言い方も 忘用できるように、フリーマーケットを開催する活動を導入した。具体的な導入方法 は下記の通りである。

\section{表 4 実践的な活動の流れ}

\begin{tabular}{|c|c|}
\hline 活動 & 内容 \\
\hline 1、文化紹介 & $\begin{array}{l}\text { 日本のさまざまな安売りの方法やその時期、100 円ショップな } \\
\text { どの店を写真で紹介する。その後、グループでディスカッシ } \\
\text { ヨンを行い、日本と香港の值引き文化の共通点と違いを考え } \\
\text { てもらう。 }\end{array}$ \\
\hline 2、ディスカッション & $\begin{array}{l}\text { 次の活動のために、日本での值引きの方法や言い方について } \\
\text { みんなで話し合う。教師が学習者のディスカッションをまと } \\
\text { める。 }\end{array}$ \\
\hline 3、実践的な活動 & $\begin{array}{l}\text { 今まで勉強した内容を活用してフリーマーケットを開催す } \\
\text { る。 }\end{array}$ \\
\hline
\end{tabular}

このように教室内での学習を終えてから、実践的な活動を行うことで、学習者は日 本語で実際に安く買い物ができたという達成感を持つことができると同時に使いたい 表現が出てこないなど自分が足りない点を再確認することができる。そうすることで、 学習者の日本語に対する学習意欲がさらに高まるのではないだろらか。また、学習者 同士のコミュニケーションや人間関係の構築にも役に立つと考えられる。

\section{5. 今後の課題}

本稿では「買い物」を会話教材の一つのテーマとして選び、ドラマやテレビ番組か ら適した場面を取り入れ教材開発を試みた。しかしながら、実際のコミュニケーショ ン場面は山ほどあり、テーマ毎に膨大なリソースから探すのは大変時間と手間がかか る作業である。そのため、日本で実際の会話場面を録音・録画したり、日本人に直接 インタビューしたりするなど、より簡単に多くの生教材を得る方法もあるのではない かと、教材作成を通して今は考えている。そして、今回作成した教材を実際の授業で 活用し、学習者からフィードバックをもらい、今後さらに改善できればと考えている。 


\section{参考文献}

小山悟(2002)『J. Bridge ジェイ・ブリッジ』凡人社

小山悟(2008)「プロフィシェンシー重視の初級教育ートピック・ベースのシラバス・デザインー」 鎌田修・嶋田和子・迫田久美子（編）『プロフィシェンシーを育てる一真の日本語能力をめざして 一』凡人社. pp. 184-209

ラミレス・ハラ，ホセ・アントニオ(2009）「学習者が話せるようになる授業への改善の試みーペルー日 系人協会日本語・語学センターの初級を例に一」日本言語文化研究会論集 2009 年第 5 号

Long, M. \& Crookes, G. (1992). Three approaches to task-based syllabus design, TESOL Quarterly, 26 (1), pp. 27-56. 
○コンビニで買い物をしよう

1 会話を聴いてみましょう。空いているところに数字を入れてください。 円頂戴いたします。

円お預かりいたします。

お先に、

どうぞ。

一.

、——モと

円お返しいたします。

ありがとうごさいます。またお越しくださいませ。

2 下記の表現に気をつけながら、もうー度聞いてみましょう。

(1)頂戴いたします。(ちょうだいいたします)：

「もらいます」のとても丁寧な言い方。ほかに「いただきます」とも言う。

(2)お預かりいたします。(おあずかりいたします)：

「受け取ります」のとても丁寧な言い方。

(3)お返しいたします。(おかえしいたします)：

お釣りを返す時の決まり文句。店員は客に見せながらお金を数える。

(4)またお越しくださいませ。（またおこしくださいませ） 「また来てください」のとても丁寧な言い方。

3 みんなが店員になって、お金を数えましょう。
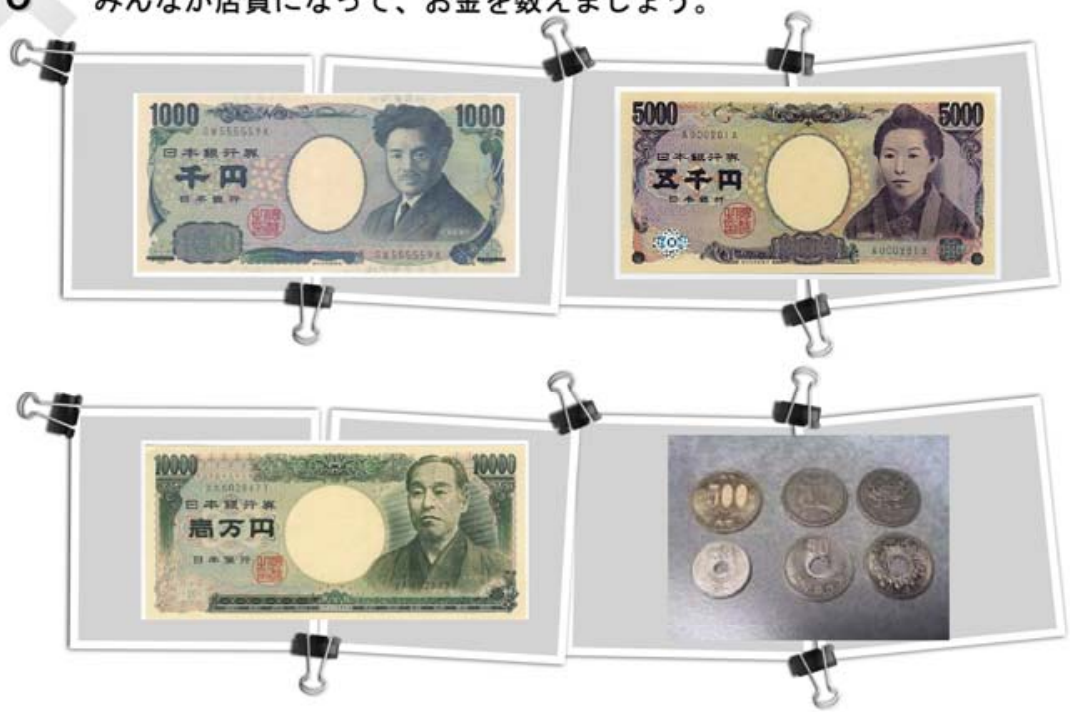


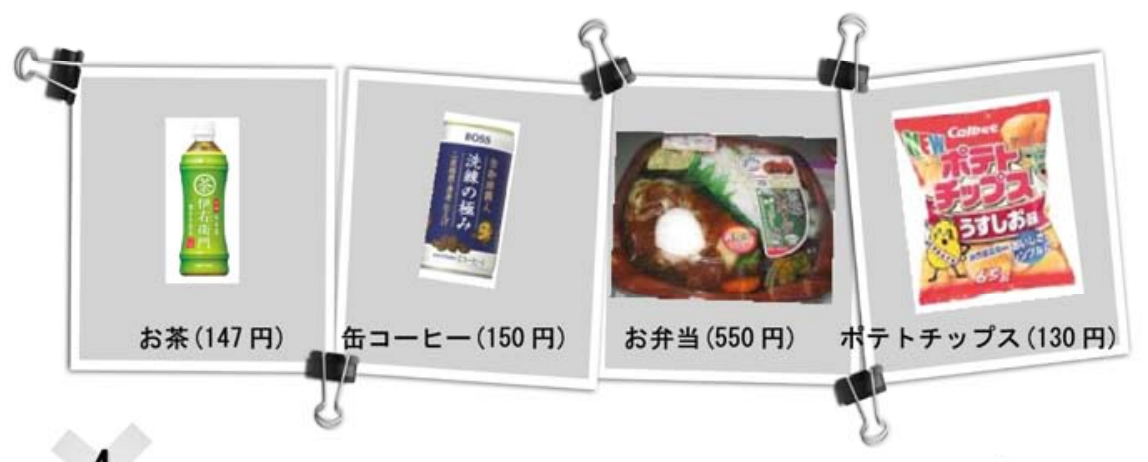

4 コンビニについてペアで話しましょう。

例 : 周りにコンビニが多いですか。いつからコンビニがありますか。

香港（地元）で有名なコンビニは何でしょうか。

よくコンビニに行きますか。

よくコンビニで何を買いますか。

買い物以外に、どんな時にコンビニを利用していますか。

5 ビデオを見て、日本のコンビニのサービスを勉強しましょう。
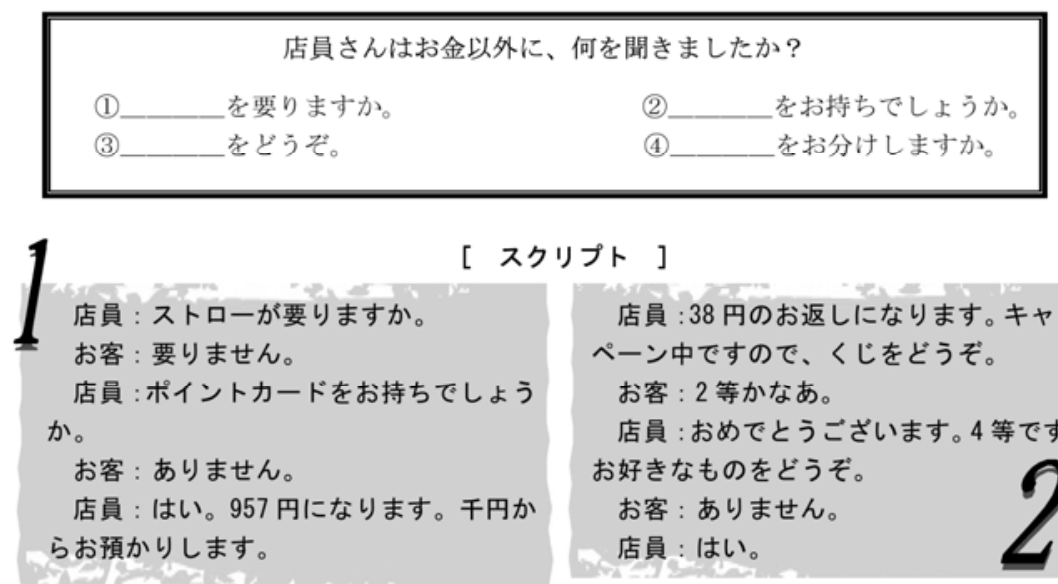

店員 $: 38$ 円のお返しになります。キャン ペーン中ですので、くじをどうぞ。 お客 : 2 等かなあ。

店員 : おめでとうございます。 4 等です。 お好きなものをどうぞ。

お客 : ありません。

店員：はい。

店員: いらつしやいませ。 420 円が 1 点、 126 円が 1 点、 428 円が 1 点、お会計 1184 円で ごさいます。1 万円お預かりいたします。冷たいもの、袋をお分けしますか。 お客 : いえ、大丈夫です。

店員 : かしこまりました。1万円からお預かりいたします。

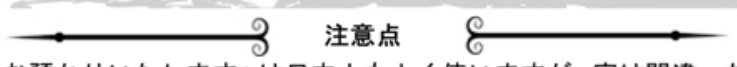

「○○円からお預かりいたします」は日本人もよく使いますが、実は間違った表現です！ 正確な言い方は「○O円頂戴致します」、「○○円お預かりいたします」です。要注意！ 
6 写真を見ながら、例のように、練習しましょう。

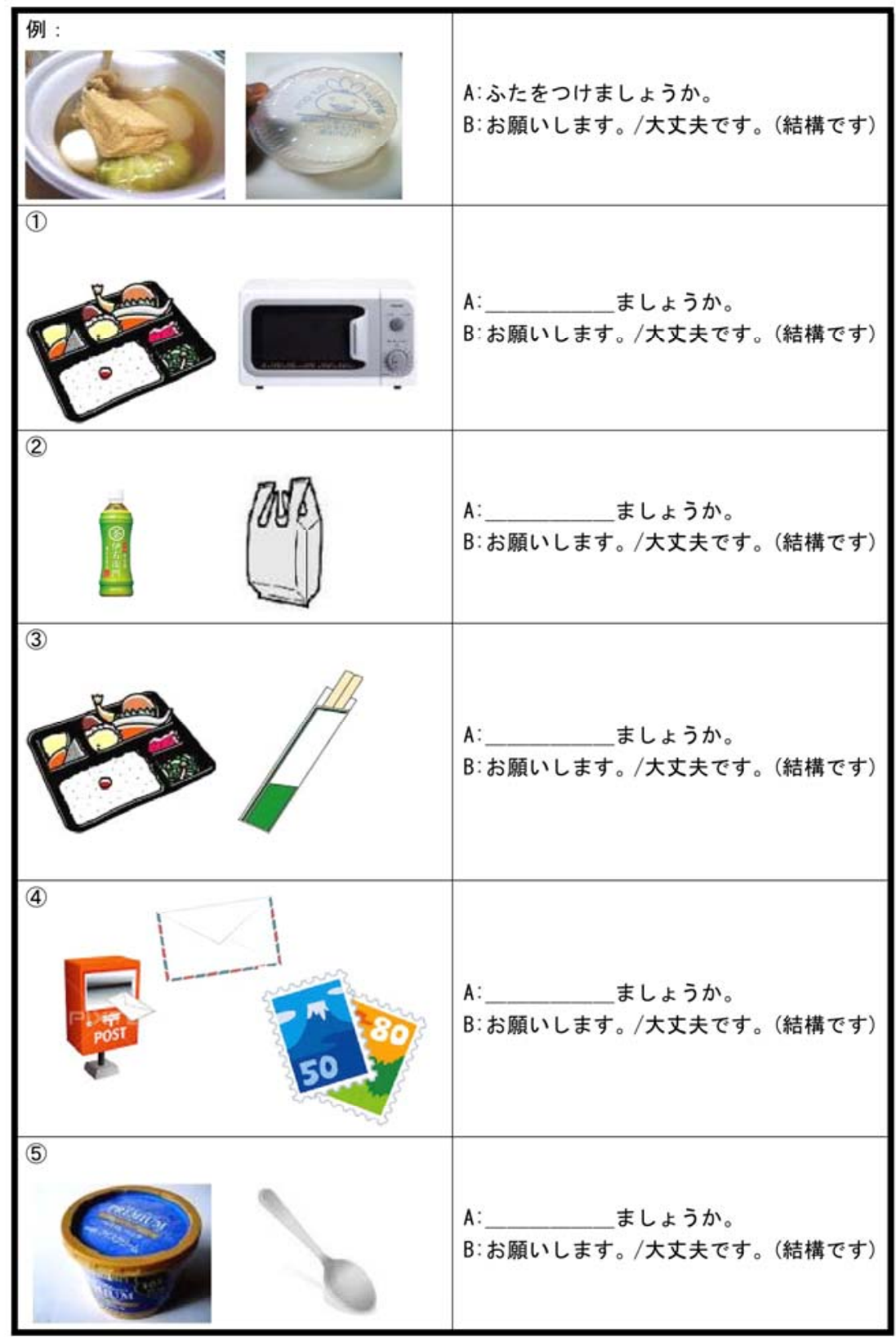




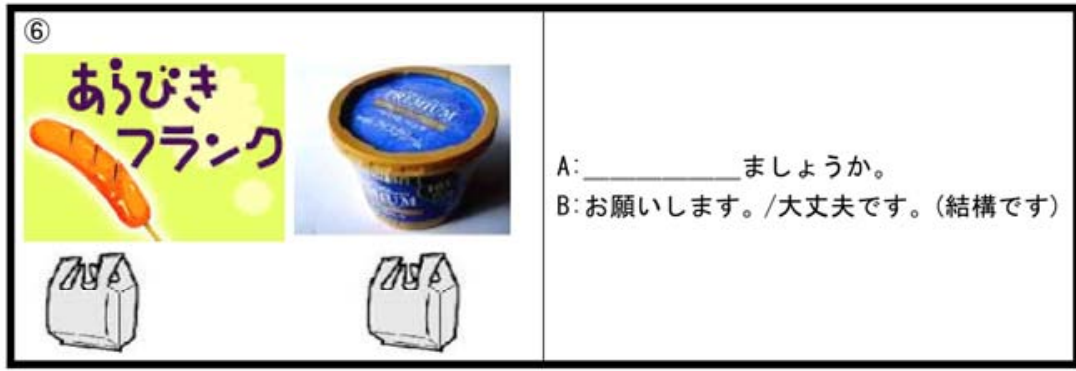

7 カードを使って、ペアでコンビニでの買い物の会話を作りましょう。

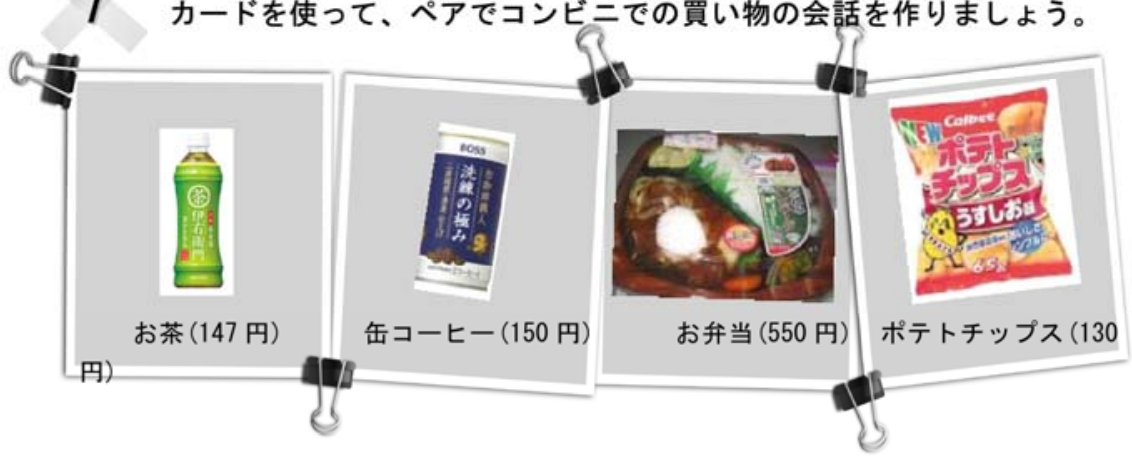

\section{デパートで買い物をしよう}

$$
\text { ロールプレイ I }
$$

カードに提示された内容を参照にしながら、ペアで練習してみてください。

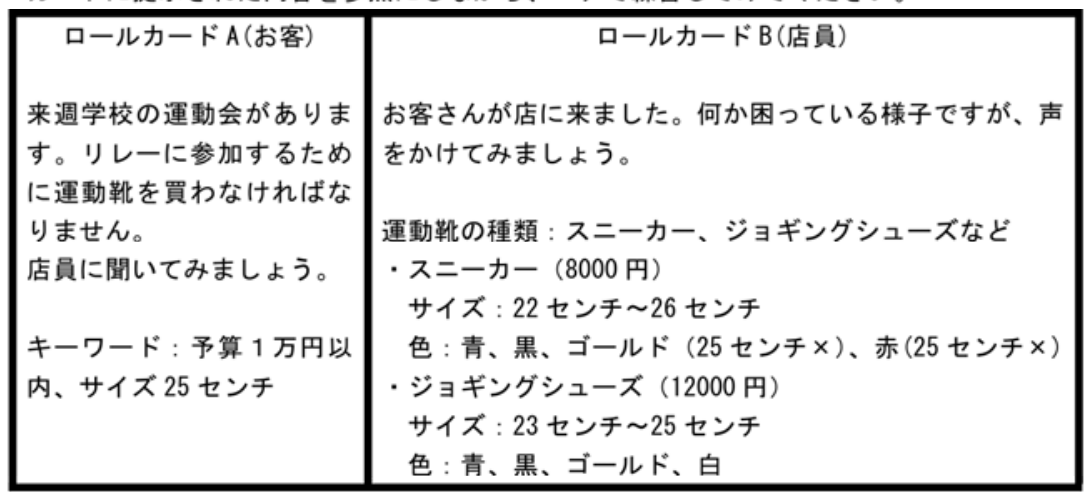


2 彼らはどこで何を買おうとしているでしょうか。ビデオを見ながら考 えてみてください。

\begin{tabular}{|l|l|}
\hline $\begin{array}{l}\text { (1)場所 : } \\
\text { 買いたい物： }\end{array}$ & $\begin{array}{l}\text { (2)場所 : } \\
\text { 買いたい物 : }\end{array}$ \\
\hline & \\
\hline $\begin{array}{l}\text { (3)場所 : } \\
\text { 買いたい物 : }\end{array}$ & $\begin{array}{l}\text { (4)場所 : } \\
\text { 買いたい物 : }\end{array}$ \\
\hline
\end{tabular}

[スクリプト $]$

大野 : 僕に似合うおすすめ シャツとかありますか。

店員 : おすすめですか。

おすすめのほうがやっぱりあの シ シャツです。

大野 : これですか。

店員 : はい。

大野 : かわいいですよね。

店员：そうですね。

大野 : じゃこれでお願いします。

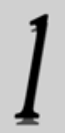

櫻井 : こんにちは。

一番派手なのありますか。

店員 : 一番派手なのは $\cdots$

上と下とどちらがよろしいですか。

櫻井 : どちらも。

店員：どちらもで。はい。

櫻井 : つうかかわいいな…

店員：お待たせ致しました。

櫻井 : 派手だな!でも春っぽいけどね。

店員：ちょっと派手すぎですか。

櫻井 : ああ、派手っすね。（派手ですね） セットアップね。

店員：はい。

櫻井 : 若干行きたくなってるんだよな。 (試着中)

店員 : お疲れ様です。

櫻井 : お疲れ様です。

店員：でも、全然いいです。 かわいいです。

櫻井 : そうなんだよね。

単語リスト

\begin{tabular}{|l|l|l|}
\hline おすすめT シャツ & recommended pick & 推荐款式 \\
\hline $\begin{array}{l}\text { はで } \\
\text { 派手 }\end{array}$ & be flashily [loudly] & 华丽, 花哨 \\
\hline $\begin{array}{l}\text { はるっぽい } \\
\text { 春っぽい }\end{array}$ & spring-Iike & 春天的气息 \\
\hline
\end{tabular}




\begin{tabular}{|l|l|l|}
\hline つうか(ていうか) & $\begin{array}{l}\text { I mean (used at the } \\
\text { beginning of a sentence) }\end{array}$ & 话说, 话题转折 \\
\hline セットアップ & Set up & 一套, 套装 \\
\hline $\begin{array}{l}\text { じゃっかん } \\
\text { 若干 }\end{array}$ & a trifle, a bit, a little & 少许, 有些 \\
\hline
\end{tabular}

3 会話を聞いて下記の問題を答えてください。

(1お客が買った服は次のどれですか。

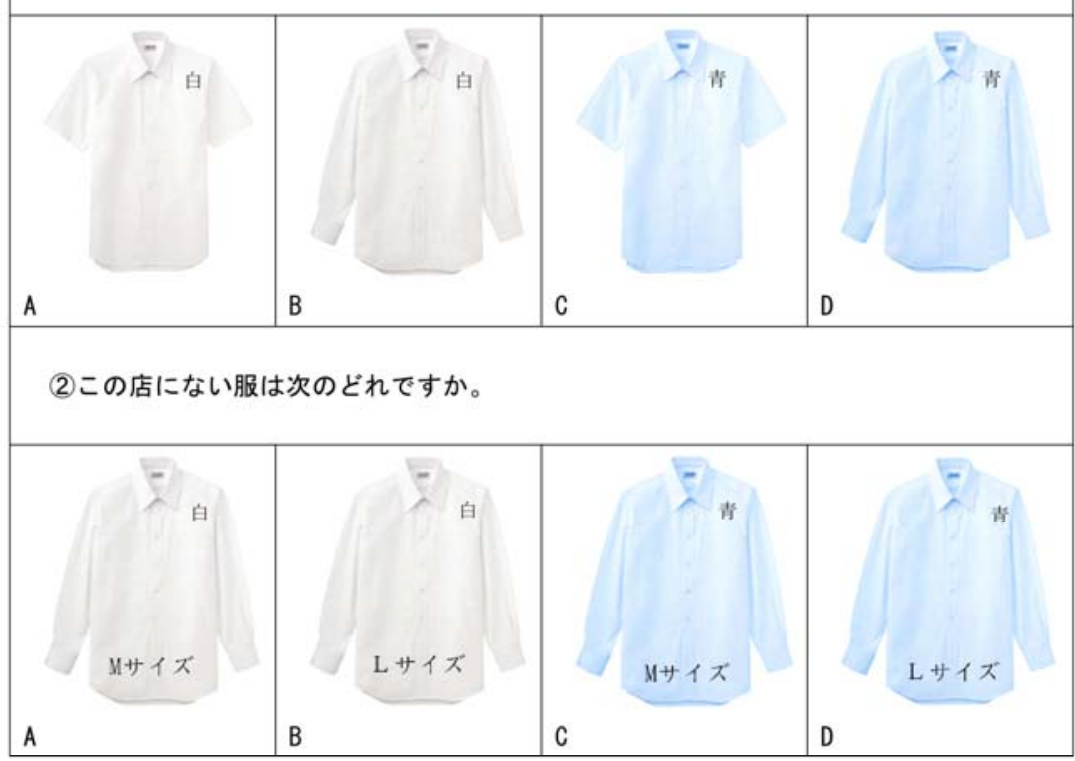

\section{モデル会話}

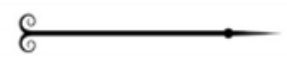

A いらっしやいませ。何かお探しですか。

B あの‥シャツを買いたいんですが、シンプルなものはありますか。

A シンプルなものでしたら、こちらはいかがでしょうか。

B ええ、この白いシャツはいいですね。ちょっと試着してもいいですか。

A はい。こちらは半袖と長袖がありますが、どちらがよろしいでしょうか。

B 長袖でお願いします。

A かしこまりました。少々お待ちください。

お待たせいたしました。こちらの試着室へどうぞ。

B ありがとうございます。

(試着中) 


\section{A お疲れ様です。}

サイズはいかがでしょうか。

B えっと、腕と肩がちょっときついです。もっと大きいサイズはありますか。

A すみません。こちらはMサイズしかごさいません。

他の色ならサイズは揃っておりますが、青、ピンク、黄色になります。

お持ち致しましょうか。

B じゃ、青のしサイズをください。

A かしこまりました。ご試着になりますか。

B はい、よろしくお願いします。

(試着中)

A いかがでしょうか。

B Lサイズはちょうどいいですね。

A とてもお似合いです。

B じゃ、これにします。

A はい、ありがとうございます。他に何か必要なものはありますでしょうか。

B あ、これでいいです。

A かしこまりました。

単語リスト

\begin{tabular}{|l|l|l|}
\hline $\begin{array}{l}\text { はんそで } \\
\text { 半袖 }\end{array}$ & short - sleeved & 半袖(衫) \\
\hline $\begin{array}{l}\text { ながそで } \\
\text { 長袖 }\end{array}$ & long-sleeved & 长袖（衫） \\
\hline $\begin{array}{l}\text { しちゃくしつ } \\
\text { 試着室 }\end{array}$ & a fitting room & 试衣间 \\
\hline $\begin{array}{l}\text { そろう } \\
\text { 揃う }\end{array}$ & Become complete & 齐全 \\
\hline ちょうどいい & suitable & 正好 \\
\hline
\end{tabular}

4 下記の表現はそれぞれ誰がどんな時に使いますか。一緒に確認してみ

ましょう。

(1) ‥はありますか。/がほしいですが…

(2) ちょっと試着してもいいですか。にれは試着できますか。

(3) もっと大きいサイズはありますか。

(4) これをください/これでお願いします/これにします

5)いらっしゃいませ。

(6) 何かお探しですか。 


\section{タスクペースの会話教材}

(7) ‥がありますが、どちらがよろしいでしょうか。

8) ․でお願いします/がいいです

9)かしこまりました。

10 少々お待ちください。/お待たせいたしました。

‥でしたら/なら、‥いかがでしょうか。

(11) お持ち致しましょうか。

12 ご試着になりますか。

13 とてもお似合いです。

14 他に何か必要なものはありますでしょうか。

\section{5 ロールプレイ II}

上記の表現を使って、もう一度練習してみましょう。

タスク 1

\begin{tabular}{|c|c|}
\hline 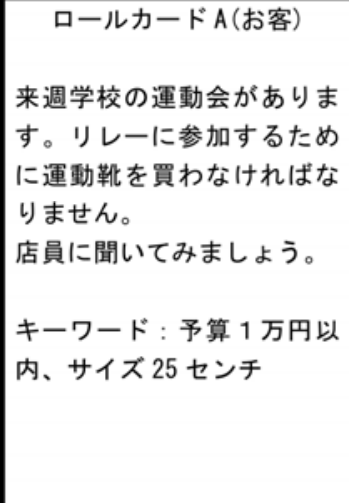 & 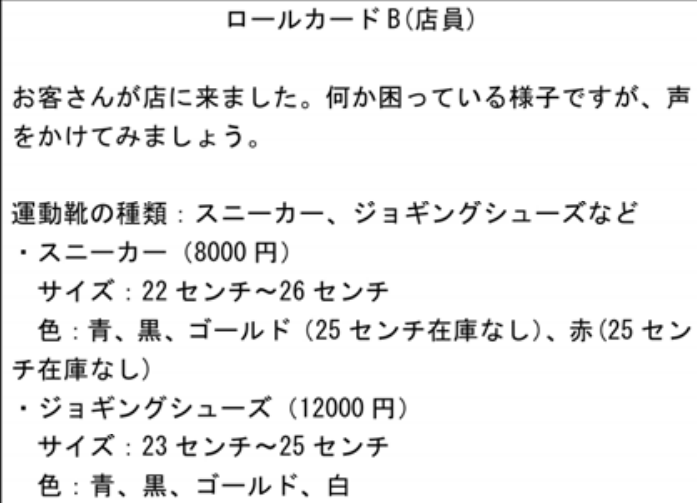 \\
\hline
\end{tabular}

タスク 2

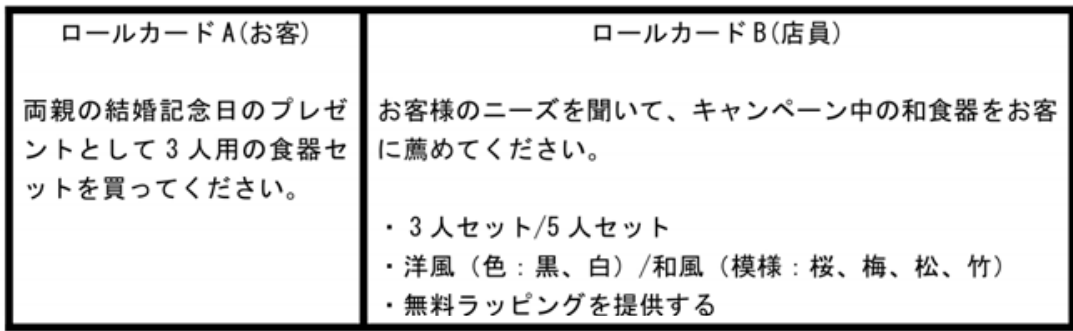




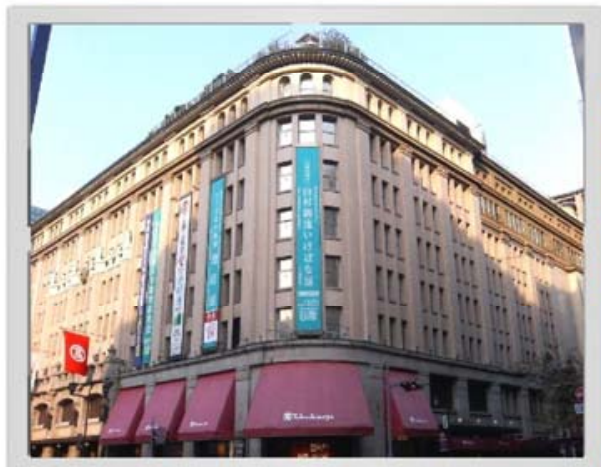

デパートのバーゲン
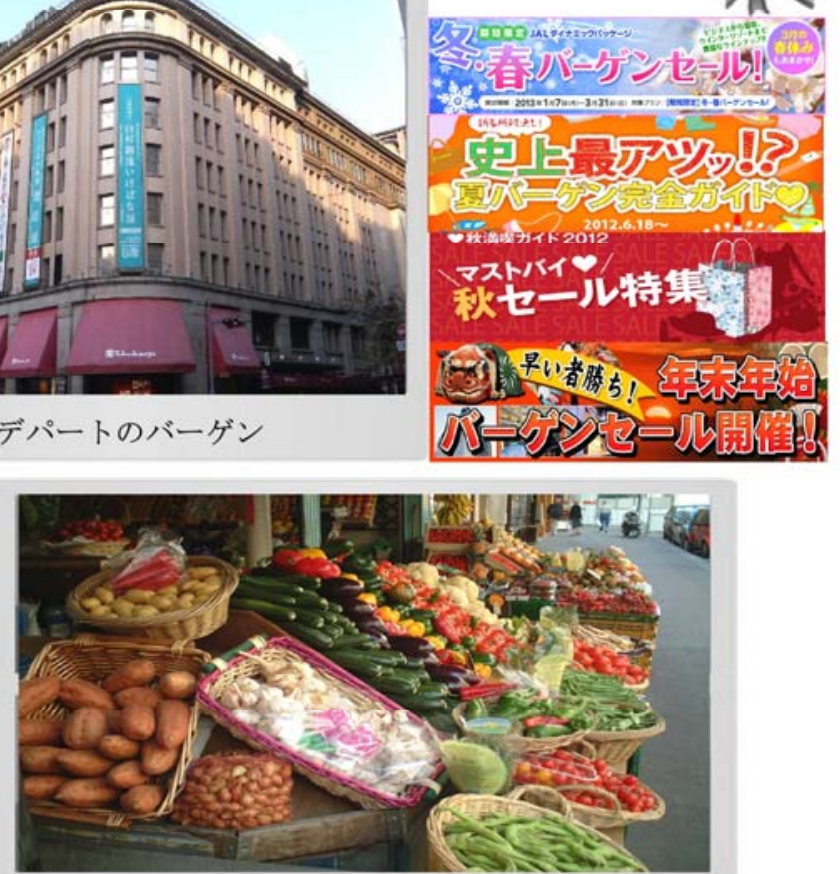

八百屋のおまけ
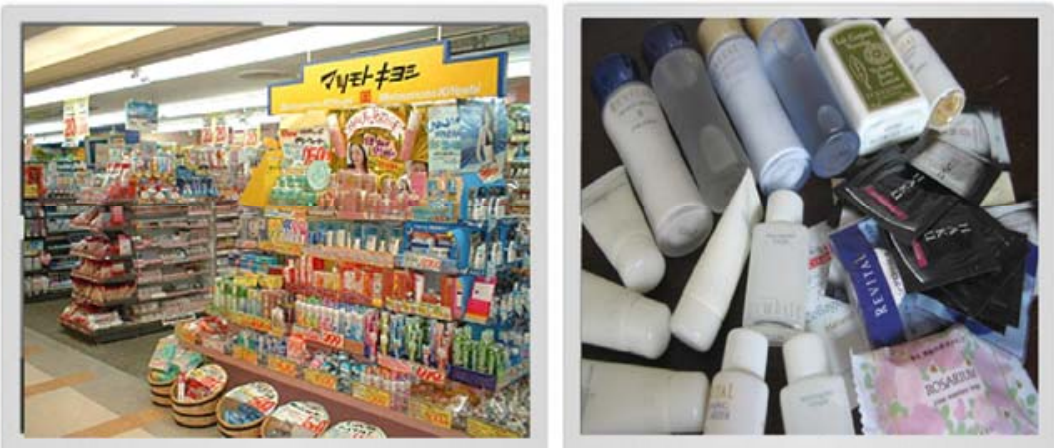

薬局のサンプル 


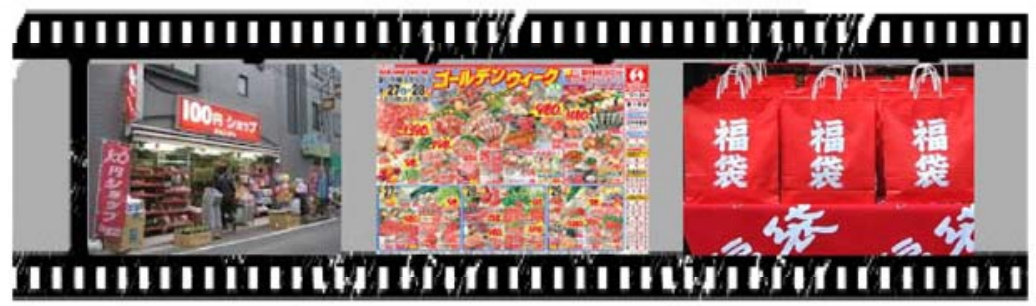

100 円ショップ スーパーの特売日

福袋

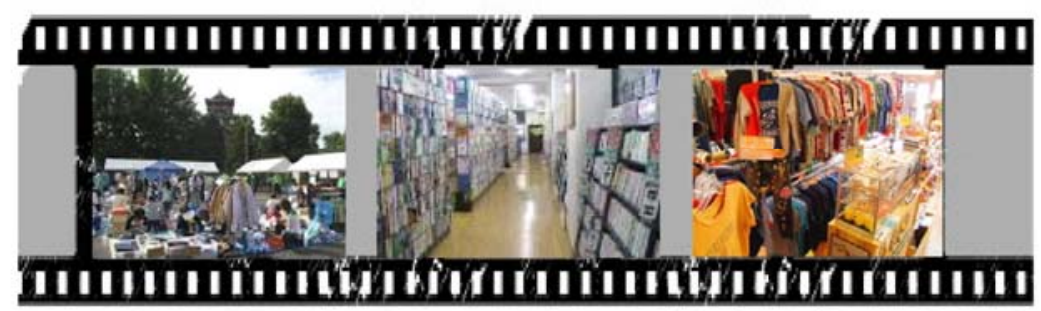

フリーマーケット

中古ショップ

古着屋

2

以下の内容についてグループで話し合ってみましょう。

(1)香港でどこで安い物が買えますか?日本と同じ所と違う所を比較してみましょう。 (2)值引きをしようとする時、どういう言い方をしますか? 日本語に変えたら言えますか?

3 クラスでフリーマーケットを開催しましょう。

みんなは自分の使っていないものを教室に持ってきて、売ってみましょう。 日本語でものを紹介したり、値引きをしたりしてください。母語禁止です。 最後は、どのぐらいのお金で何を買ったかをクラスで発表してください。

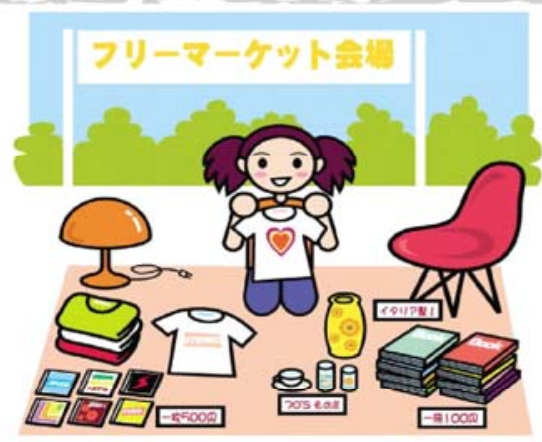

